\title{
演算子法による各種の連続ばりの解析
}

\section{OPERATIONAL METHOD FOR VARIOUS CONTINUOUS BEAMS}

\author{
吉 沢 孝 和* - 谷 本 勉之助** \\ By Norikazu Yoshizawa and Bennosuke Tanimoto
}

\section{1. まえがき}

構造解析へのマトリクス代数の応用は, 近年の電子計 算機の普及と相まって，急速な発展を示してきた ${ }^{1)}$ 。 ここに述べる演算子法 (operational method) もまた， マトリクス代数による構造解析の一法であるが, これは 筆者の 1 人が先年, ASCE 誌上に発表した 2 編の論

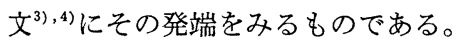

本文では，骨組構造解析の基礎ともなるべき連続ばり の解析について記述した。ここで取り扱ったものは, 普 通のはり, 弾性床上のはり, および軸圧力を受けるはり の3 種類の系であるが, 解析手順の上から共通な性質を 有する事項については, すべて表にまとめ, 全体として 総合的な記述を試みた。なお, 本文は, 信州大学工学部

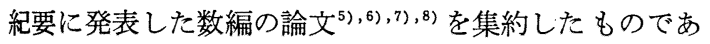
る。

\section{2. 演算子法の概要}

演算子法に関する基本的な思想とその手順を, 連続ば りの場合について要約するとつぎのようである。

(1) 一般に, ネットワーク系構造物は, トポロジカ ルな構成単位 (ユニット) の集合体であると考えること ができる。本文で取り扱う連続ばりの構造体系は, 構成 要素たるそれぞれの径間が相互に結合されて形成された ものである。したがって各径間をユニットとみたてて解 析を進める。

（2）ユニットの力学的な挙動を支配するパラメータ 一を1本の列ベクトルに並ベ，これをそのユニットの 固有マトリクス (eigenmatrix) $)^{9), 10)}$ と名づける。連続ば りの解析では, この固有マトリクスの要素として, はり の曲げに関する微分方程式の一般解の積分定数群が用い

\footnotetext{
* 正会員信州大学助手 工学部土木工学科
}

** 正会員 工博 - 理博 信州大学教授 工学部土木工学科
られる。

(3) 隣り合う径間 $(i-1)$ および径間 (i) の間にお ける適合条件と平衡条件とを系統的に処理すると，これ ら 2 つの径間の固有マトリクスの間につぎのような溸化 式が導かれる。本法ではこれを移行公式 (shift formula) と呼ぶ。

$$
N_{i}=S_{i} N_{i-1}+F_{i} K_{i-1}
$$

ここに, $N_{i-1}, N_{i}$ は径間 $(i-1)$, (i) の固有マトリ クスである。 $S_{i}$ は一方の固有マトリクスを他方のそれ に移行するための移行演算子 (shift operator) ${ }^{3), 4)}, \boldsymbol{F}_{i}$ は 荷重の影響を導入する補給演算子 (feed operator) ${ }^{5), 6)}$, $\boldsymbol{K}_{i-1}$ は径間 $(i-1)$ の荷重項 (load term) $\left.{ }^{6}\right)$ である。

（4）与えられた系について基準となる径間を選定 し，その固有マトリクスを移行公式により系全体に流通 させる。よってこのように選ばれた固有マトリクスを流 通マトリクス (current matrix) ${ }^{6)}$ と呼ぶ。

（5）流通マトリクスの值は通常, 考えている系の境 界条件によって決定される。これもまた, 系統的なマト リクス演算で処理されるが，その際，与えられた境界条 件に完全対応する演算マトリクスが導かれる。これを境 界マトリクス (boundary matrix) ${ }^{6), 10)}$ と呼ぶ。

（6）本法はこれを代数学的にみるならば，各種の性 質の異なるデータを完全に分類整理して導かれたところ のマトリクス演算子による解析法といえよう。流通マト リクスの移行演算は, 各種の演算子の単なる内積計算に 㷌着し, 解析の最終段階において, 流通マトリクスの值 を決定するための逆マトリクス計算を必要とするだけで ある。このような手法により，構造解析の思想も計算 も，きわめて平易なものとなしらる。

また, 本文で述べるはりの基本式に, 事前に特定の境 界条件を与えて処理することにより,三連モーメント法, たわみ角法，モーメント分配法等の在来の各種の曲げ理 論式 ${ }^{11)}$ が得られ, 演算子法的見地からそれらの特性を説 明することができる ${ }^{12)}$ 。さらにレダクション法との関連 性 ${ }^{13)}$ についても, 同様の考察が可能である。なお, 本法 
の思想と手順を在来の応力法, 変形法等に応用して, か なり良い改良点と成果を得ている ${ }^{14), 15)}$ 。これらの問題に 関する記述はまた別の機会にゆずりたい。

\section{3. 基 本 式}

ここでは，はりの解析において用いられる基本式を示 す。本法では座標はすべて無次元化したものを用いてい る。すなおち, はりの中立軸上の任意点の座標は $\rho=x / L$ で与えられる。ここに $x=$ はりの左端から右向きにとっ た流通座標， $L=$ 核りの長さである。

一般に，はりの任意点 $\rho$ における物理量は次式で与え られる：

$$
\boldsymbol{W}(\rho)=\boldsymbol{D P}(\rho)[\boldsymbol{N}+\boldsymbol{K}(\rho)]
$$

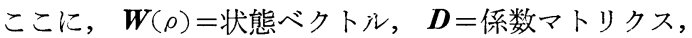
$\boldsymbol{P}(\rho)$ 座標マトリクス, $\boldsymbol{N}=$ 固有マトリクス, $\boldsymbol{K}(\rho)$ ＝荷重マトリクスである。これらのマトリクスに関する 定義を以下に示す。

\section{（1） 状態ベクトル (state vector) $\boldsymbol{W}(\boldsymbol{\rho})^{16), 17)}$}

はり上の一点 $\rho$ におる物理量をひとつの列ベクトル に並べたものである。すなわち，

$$
\boldsymbol{W}(\rho)=\left\{\begin{array}{llll}
w & \theta & M & S
\end{array}\right\}_{\rho}
$$

ここに, 上式の列ベクトルの中の要素は順に，はりの $\rho$ 点でのたわみ, たわみ角, 曲げモーメント, せん断力を 示している。

\section{（2）係数マトリクス (coefficient matrix) $D$.}

上記のそれぞれの物理量に関倸する係数を正方マトリ クスの対角要素に並べたものである。これは各種のはり についてつぎのように与えられる：

a）普通のはり

$$
\boldsymbol{D}=\operatorname{diag}\left[\begin{array}{llll}
\frac{L^{3}}{6 E I} & \frac{L^{2}}{6 E I} & -\frac{L}{3} & -1
\end{array}\right]
$$

ここに, $E=$ 弾性倸数, $I=$ 断面二次モーメント

b）弾性床上のはり

$$
\boldsymbol{D}=\operatorname{diag}\left[\frac{L^{3}}{2 \beta^{3} E I} \frac{L^{2}}{2 \beta^{2} E I}-\frac{L}{\beta}-1\right] \ldots
$$
ここに,

$$
\beta=\sqrt[4]{\frac{K L^{4}}{4 E I}}, K=\text { 地盤係数 }
$$

c）軸圧力を受けるはり

$$
\boldsymbol{D}=\operatorname{diag}\left[\frac{L^{3}}{\alpha^{3} E I} \frac{L^{2}}{\alpha^{2} E I}-\frac{L}{\alpha}-1\right]
$$

ここに，

$$
\alpha=\sqrt{\frac{Q L^{2}}{E I}}, Q=\text { 軸圧力 }
$$

\section{（3）座標マトリクス (abscissa matrix) $\boldsymbol{P}(\boldsymbol{\rho})$}

はりの座標に関倸したマトリクスで，上記の状態ベク トルの各要素に対応してつぎのように与えられる：

a) 普通のはり

$$
\boldsymbol{P}(\rho)=\left(\begin{array}{cccc}
1 & \rho & \rho^{2} & \rho^{3} \\
0 & 1 & 2 \rho & 3 \rho^{2} \\
0 & 0 & 1 & 3 \rho \\
0 & 0 & 0 & 1
\end{array}\right)
$$

b）弾性床上のはり

$$
\boldsymbol{P}(\rho)=\left(\begin{array}{cccc}
\psi_{1} & \psi_{2} & \psi_{3} & \psi_{4} \\
\psi_{1}-\psi_{2} & \psi_{1}+\psi_{2} & -\psi_{3}-\psi_{4} & \psi_{3}-\psi_{4} \\
-\psi_{2} & \psi_{1} & \psi_{4} & -\psi_{3} \\
-\psi_{1}-\psi_{2} & \psi_{1}-\psi_{2} & \psi_{3}-\psi_{4} & \psi_{3}+\psi_{4}
\end{array}\right)
$$

ここに，

$$
\left.\begin{array}{l}
\psi_{1}=e^{\beta \rho} \cos \beta \rho, \psi_{2}=e^{\beta \rho} \sin \beta \rho, \\
\psi_{3}=e^{-\beta \rho} \cos \beta \rho, \psi_{4}=e^{-\beta \rho} \sin \beta \rho
\end{array}\right\}
$$

c）軸圧力を受けるはり

$$
\boldsymbol{P}(\rho)=\left(\begin{array}{cccc}
1 & \alpha \rho & \cos \alpha \rho & \sin \alpha \rho \\
0 & 1 & -\sin \alpha \rho & \cos \alpha \rho \\
0 & 0 & -\cos \alpha \rho & -\sin \alpha \rho \\
0 & 0 & \sin \alpha \rho & -\cos \alpha \rho
\end{array}\right) \cdots \cdots(1
$$

\section{（4）固有マトリクス (eigenmatrix) N}

はりの曲げの微分方程式の一般解の積分定数群を列べ クトルに並べたもので，次式で与えられる：

$$
\boldsymbol{N}=\left\{\begin{array}{llll}
A & B & C & D
\end{array}\right\} .
$$

考えているはりの力学挙動はすべてこの固有マトリクス によって支配されることになる。

式 (3) に示した状態ベクトル $\boldsymbol{W}(\rho)$ と固有マトリ クス $N$ とは全完に対応している。

\section{（5）荷重マトリクス（load-matrix) $\boldsymbol{K}(\rho)$}

図一1 ははりに作用する外力に関する荷重マトリクス の取扱い方を示したものである。荷重の作用点の座標 $\xi$ もまた無次元化して $\kappa=\xi / L$ で表わすことにしている。 荷重の作用点に扔いて, 状態ベクトルの連続条件を式

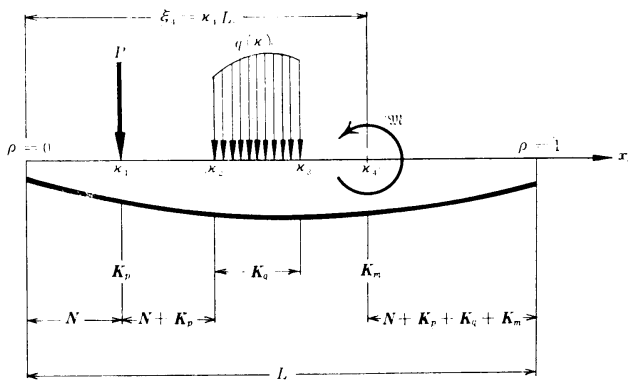

図一1荷重マトリクス 
（2）に注目して処理すると荷重マトリクスが得られ る。これを用いると, 荷重の影響は単に, 固有マトリク ス $N$ にそれぞれの荷重点で当該荷重に関寸る荷重マト リクスを加えこむことによって処理されることになる。

$$
\begin{aligned}
& 0<\rho<\kappa_{1}: \boldsymbol{W}(\rho)=\boldsymbol{D P}(\rho) \boldsymbol{N} \\
& \kappa_{1}<\rho<\kappa_{2}: \boldsymbol{W}(\rho)=\boldsymbol{D P}(\rho)\left[\boldsymbol{N}+\boldsymbol{K}_{p}\right] \\
& \kappa_{2}<\rho<\kappa_{3}: \boldsymbol{W}(\rho)=\boldsymbol{D P P}(\rho)\left[\boldsymbol{N}+\boldsymbol{K}_{\boldsymbol{p}}+\boldsymbol{K}_{q}(\rho)\right] \\
& \kappa_{3}<\rho<\kappa_{4}: \boldsymbol{W}(\rho)=\boldsymbol{D P}(\rho)\left[\boldsymbol{N}+\boldsymbol{K}_{\boldsymbol{p}}+\boldsymbol{K}_{q}\right] \\
& \kappa_{4}<\rho<1: \boldsymbol{W}(\rho)=\boldsymbol{D P}(\rho)\left[\boldsymbol{N}+\boldsymbol{K}_{\boldsymbol{p}}+\boldsymbol{K}_{\boldsymbol{q}}+\boldsymbol{K}_{\boldsymbol{m}}\right]
\end{aligned}
$$

ここにそれぞれ， $\boldsymbol{K}_{p}=$ 集中荷重， $\boldsymbol{K}_{q}=$ 分布荷重， $\boldsymbol{K}_{m}$ ＝外力モーメントによる荷重マトリクスである。各種の はりについて、これらはつぎのように与えられる：

a) 普通のはり

$$
\begin{aligned}
& \boldsymbol{K}_{p}=-P\left\{\begin{array}{lllll}
-\kappa_{1}{ }^{3} & 3 \kappa_{1}{ }^{2} & -3 \kappa_{1} & 1
\end{array}\right\} \\
& \boldsymbol{K}_{q}=L \int_{\kappa_{2}}^{\kappa_{3}} q(\kappa)\left\{\begin{array}{lllll}
-\kappa^{3} & 3 \kappa^{2} & -3 \kappa & 1\} d \kappa \\
\boldsymbol{K}_{m} & =\frac{3}{L} \mathfrak{M}\left\{\kappa_{4}{ }^{2}\right. & -2 \kappa_{4} & 1 & 0
\end{array}\right\}
\end{aligned}
$$

b）弾性床上のはり

$$
\left.\begin{array}{l}
\boldsymbol{K}_{p}=\frac{P}{4}\left\{-\psi_{3}-\psi_{4} \psi_{3}-\psi_{4} \psi_{1}-\psi_{2} \psi_{1}+\psi_{2}\right\}_{\kappa_{1}} \\
\boldsymbol{K}_{q}=\frac{L}{4} \int_{\kappa_{2}}^{\kappa_{3}} q(\kappa)\left\{-\psi_{3}-\psi_{4} \psi_{3}-\psi_{4} \psi_{1}-\psi_{2} \psi_{1}+\psi_{2}\right\} d \kappa \\
\boldsymbol{K}_{m}=\frac{\beta M}{2 L}\left\{-\psi_{4} \psi_{3} \psi_{2}-\psi_{1}\right\}_{\kappa_{4}}
\end{array}\right\}
$$

c) 軸圧力を受けるはり

$$
\begin{aligned}
& \boldsymbol{K}_{p}=P\left\{\begin{array}{llll}
-\alpha \kappa_{1} & 1 & \sin \alpha \kappa_{1} & -\cos \alpha \kappa_{1}
\end{array}\right\} \\
& \boldsymbol{K}_{q}=L \int_{\kappa_{2}}^{\kappa_{3}} q(\kappa)\{-\alpha \kappa 1 \sin \alpha \kappa-\cos \alpha \kappa\} d \kappa \\
& \boldsymbol{K}_{m}=\frac{\alpha \mathfrak{M}}{L}\left\{1 \quad 0-\cos \alpha \kappa_{4} \quad-\sin \alpha \kappa_{4}\right\}
\end{aligned}
$$

\begin{tabular}{|c|c|c|}
\hline & 端 & $\boldsymbol{B}^{\prime}$ \\
\hline 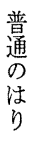 & {$\left[\begin{array}{cccc}0, & 1, & -\frac{2 E I m_{1}}{L}, & 0 \\
1, & 0, & 0, & \frac{6 E I k_{1}}{L^{3}}\end{array}\right]$} & {$\left[\begin{array}{cccc}0, & 1, & 2+\frac{2 E I m_{n}}{L}, & 3+\frac{6 E I m_{n}}{L} \\
1, & 1, & 1, & 1-\frac{6 E I k_{n}}{L^{3}}\end{array}\right]$} \\
\hline 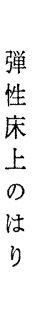 & $\left.\begin{array}{rcc}1, & 1-\frac{2 \beta E I m_{1}}{L}, & \\
-1+\frac{L^{3}}{2 \beta^{3} E I k_{1}}, & 1, & \\
-1, & 1+\frac{2 \beta E I m_{1}}{L} \\
1+\frac{L^{3}}{2 \beta^{3} E I k_{1}}, & 1\end{array}\right]$ & $\begin{array}{l}{\left[\begin{array}{l}\phi_{1}-\left(1+\frac{2 \beta E I m_{n}}{L}\right) \phi_{2}, \quad\left(1+\frac{2 \beta E I m_{n}}{L}\right) \phi_{1}+\phi_{2}, \\
\left(1+\frac{L^{3}}{2 \beta^{3} E I k_{n}}\right) \phi_{1}+\phi_{2}, \quad-\phi_{1}+\left(1+\frac{L^{3}}{2 \beta^{3} E I k_{n}}\right) \dot{\phi}_{2}, \\
\quad-\phi_{3}-\left(1-\frac{2 \beta E I m_{n}}{L}\right) \phi_{4}, \quad\left(1-\frac{2 \beta E I m_{n}}{L}\right) \phi_{3}-\phi_{4}\end{array}\right.} \\
\quad\left(-1+\frac{L^{3}}{2 \beta^{3} E I k_{n}}\right) \phi_{3}+\phi_{4}, \quad-\phi_{3}+\left(-1+\frac{L^{3}}{2 \beta^{3} E I k_{n}}\right) \phi_{4}\end{array}$ \\
\hline $\begin{array}{l}\text { 軸 } \\
\text { 力 } \\
\text { は } \\
\text { b }\end{array}$ & {$\left[\begin{array}{cccc}0, & 1, & \frac{\kappa E I m_{1}}{L}, & 1 \\
1, & 0, & 1, & -\frac{\alpha^{8} E I k_{1}}{L^{3}}\end{array}\right]$} & {$\left[\begin{array}{cccc}0, & -1, & \sin \alpha+\frac{\alpha E I m_{n}}{L} \cos \alpha, & -\cos \alpha+\frac{\alpha E I m_{n}}{L} \sin \alpha \\
1, & \alpha, & \cos \alpha-\frac{\alpha^{3} E I k_{n}}{L^{3}} \sin \alpha, & \sin \alpha+\frac{\alpha^{3} E I k_{n}}{L^{3}} \cos \alpha\end{array}\right]$} \\
\hline
\end{tabular}

\section{4. 境界条件}

つぎにはりの境界条件について述べる。はりの境界条 件を一般的な形で表わすために, はりの両端が弾性的に 支持されている場合を考える。その状態を図一2 (a), (b) に示す。(a) は連続ばりの左端の支点, (b) は右端 の支点である。支点番号は左端から順につけてある。こ

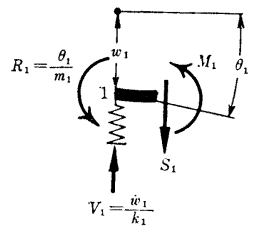

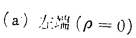

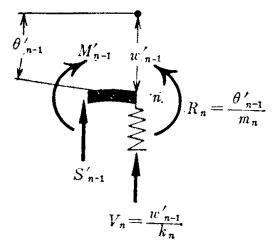

(b) 储敊 $(\rho=1)$

表一1 境界マトリクス 
左端 $(\rho=0):\left[\begin{array}{l}M \\ S\end{array}\right]_{1}+\left[\begin{array}{c}\frac{\theta}{m} \\ -\frac{w}{k}\end{array}\right]_{1}=0$

右端 $(\rho=1):\left[\begin{array}{l}M \\ S\end{array}\right]_{n-1}^{\prime}+\left[\begin{array}{c}-\frac{\theta^{\prime}{ }_{n-1}}{m_{n}} \\ \frac{w^{\prime}{ }_{n-1}}{k_{n}}\end{array}\right]=0$

ここに, 各径閒の右端 $(\rho=1)$ における物理量にはプラ イム (') をつけ, 左端 $(\rho=0)$ におけるものには何もつ けないで区別することにしている。この記法は以後，本 文全体に通用するものとする。さて, 状態ベクトルの基 本式（2）を用いれば, 式 (18)，（19）に示される境界 条件は結局，つぎの式を計算することに帰着する：

左端 $(\rho=0): \boldsymbol{B} \boldsymbol{N}_{1}=0$

右端 $(\rho=1): \boldsymbol{B}^{\prime} \boldsymbol{N}_{n-1}^{\prime}=\boldsymbol{B}^{\prime}[\boldsymbol{N}+\boldsymbol{K}]_{n-1}=0 \quad \cdots(21)$

ここに, $\boldsymbol{B}, \boldsymbol{B}^{\prime}$ は境界マトリクス (boundary matrix) と呼ばれる 2 行 4 列の矩形マトリクスである。その值は 各種のはりについて 表一1 のように与えられる。また $\boldsymbol{K}_{n-1}$ は右端の第 $(n-1)$ 径間における荷重マトリクス の総計を示し，その径間の荷重項 (load term) ${ }^{6)}$ と呼ば れる。

表一1でばね定数 $k$, $m$ の值のとり方によっ て, すべての境界条件 を処理することができ る。その例を 表一2 に 示した。このほかにも

表一2 ばね定数と境界条件

\begin{tabular}{c|c|c}
\hline & $k$ & $m$ \\
\hline 弾 性 端 & $k$ & $m$ \\
埋 込 端 & 0 & 0 \\
単 純 端 & 0 & $\infty$ \\
自 由 端 & $\infty$ & $\infty$ \\
\hline
\end{tabular}

$k, m$ の值の組み合わせ方によって, 種々の 境界条件を 設定することができる。

\section{5. 結合条件}

ここでは，連続ばりの各個の構成径間をユニットにと る。そしてそれらが横方向に結合されてひとつの構造体 系が形成されるものと考えて解析を進める。

隣り合う 2 つの構成径間の結合条件は, 結合点におけ るそれら両径間の状態ベクトルの適合条件および平衡条 件を処理することによって満足する。ここで, 連続ばり の中間支点が前記の境界条件の項で述べたのと同様に， 弾性的に支持されているものとすれば，この点での結合 条件はつぎのように表わされる：

$$
-\left[\begin{array}{c}
w \\
\theta \\
M \\
S
\end{array}\right]_{i-1}^{\prime}+\left[\begin{array}{c}
w \\
\theta \\
S \\
S
\end{array}\right]_{i}+\left[\begin{array}{c}
0 \\
0 \\
\frac{\theta}{m} \\
-\frac{w}{k}
\end{array}\right]_{i}=0
$$

ここに， $k_{i}, m_{i}$ は中間支点 $i$ におけるばね定数である。
これらの值のとり方によって，各種の結合条件を表わす ことができる。たとえば, $k_{i}=m_{i}=\infty$ とおけば, プレ 一トガーダーなどにみられる断面形状の階段的変化部に おける結合条件となる。また， $k_{i}=0, m_{i}=\infty$ とおけげ, これは剛支承における結合条件を示す。

これが, 剛支承とピンジョイントの組み合わせのみで 構成されるような連続ばり ${ }^{5)}$ の場合には, 式 (22) の形 を用いるよりも，つぎのような手順によるほうが思想上 と能率上からみて, より有効である。すなわち, 各構成 径間について, 径間の端部が剛支承につながる場合に は，たわみが 0 , ピンジョイントにつながる場合にはそ の端部の曲げモーメントが 0 といら条件を, 系全体につ いて処理する。これにより, 式 (13) に示した固有マト リクスの要素の值が 2 個確定し, 未知量が半分に減る。 このことを, たとえば, 左端が剛支承, 右端がピンジョ イントにつながる構成径間をとって考えてみると，普通 のはりの場合, 固有マトリクスはつぎの形で表わされ る :

$$
\boldsymbol{N}_{i}=\left(\begin{array}{rr}
0 & 0 \\
1 & 0 \\
0 & -3 \\
0 & 1
\end{array}\right) \boldsymbol{A}_{i}+\left[\begin{array}{rrrr}
0 & 0 & 0 & 0 \\
0 & 0 & 0 & 0 \\
0 & 0 & -1 & -3 \\
0 & 0 & 0 & 0
\end{array}\right) \boldsymbol{K}_{i}
$$

ここに,

$$
\boldsymbol{A}_{i}=\left\{\begin{array}{ll}
B & D
\end{array}\right\}
$$

また， $\boldsymbol{K}_{i}$ =荷重項である。 $\boldsymbol{A}_{i}$ を半固有マトリクス (semi-eigenmatrix) と呼ぶ5)。事前に上のような処理を したあとには，結合条件としてつぎのものを考えればよ W:

剛支承 :

$$
-\left[\begin{array}{c}
\theta \\
M
\end{array}\right]_{i-1}^{\prime}+\left[\begin{array}{c}
\theta \\
M
\end{array}\right]_{i}-\left[\begin{array}{c}
0 \\
\frac{\theta}{m}
\end{array}\right]_{i}=0
$$

ピンジョイント:

$$
-\left[\begin{array}{c}
w \\
S
\end{array}\right]_{i-1}^{\prime}+\left[\begin{array}{c}
w \\
S
\end{array}\right]_{i}-\left[\begin{array}{c}
0 \\
\frac{w}{k}
\end{array}\right]_{i}=0
$$

さて, 式 (22) に示した結合条件は, 式 (2)によっ てつぎの形に書きかえられる：

$$
C_{i}\left\{N_{i-1}^{\prime} N_{i}\right\}=0
$$

これが中間支点における結合条件式である。 $\boldsymbol{C}_{\boldsymbol{i}}$ を結合 マトリクス (connection matrix) と呼ぶ。その值は各 種のはりに対して表一3のように与えられる。

式 (25)，(26）からも同様な手法で結合マトリクスが 得られるが，その次数は式 (24) に示した半固有マトリ クスの次数に対応したものとなる。この場合, 構成径間 の両端の支持方式の組み合わせによって 7 種類の結合マ トリクスが誘導される5)。 
表一3 結 合 マトリクス $\boldsymbol{C}_{\boldsymbol{i}}$

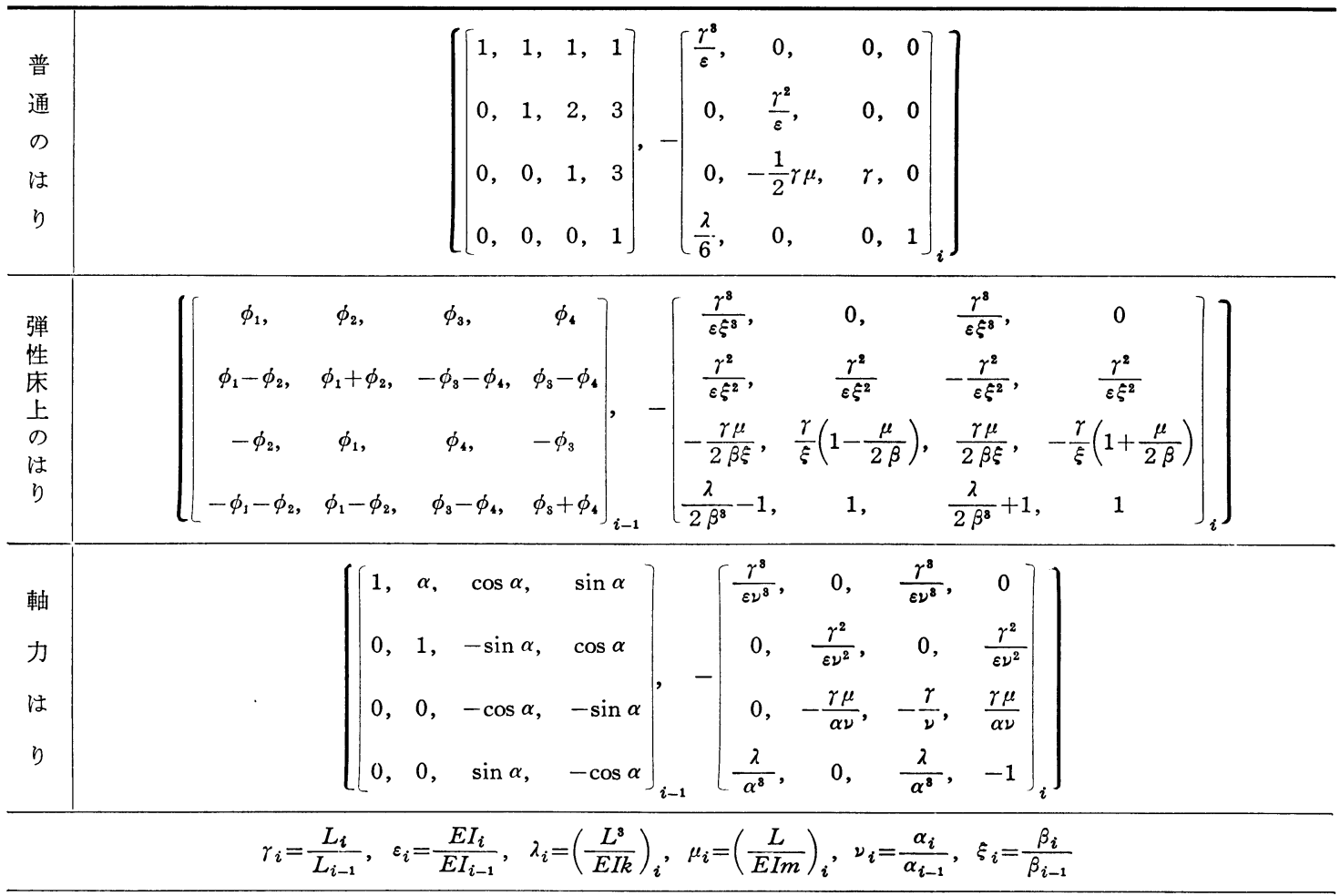

\section{6. 移行演算子}

\section{表一3 に示した結合マトリクスはいずれも$$
\boldsymbol{C}_{i}=\left[\begin{array}{ll}
c_{i-1}^{\prime} & c_{i}
\end{array}\right]
$$

の形で与えられている。 $\boldsymbol{c}^{\prime}{ }_{i-1}, \boldsymbol{c}_{\boldsymbol{i}}$ はそれぞれ 4 次の正方 マトリクスである。これを式 (27) に代入して整理すれ ば，隣り合う 2 つの径間の固有マトリクス $N_{i-1}, N_{i}$ の 間の関係がつぎのように表わされる。

$$
\begin{aligned}
& \boldsymbol{N}_{i}=-\boldsymbol{c}_{\boldsymbol{i}}{ }^{-1} \boldsymbol{c}^{\prime}{ }_{i-1}[\boldsymbol{N}+\boldsymbol{K}]_{i-1}=\boldsymbol{S}_{i}[\boldsymbol{N}+\boldsymbol{K}]_{i-1} \cdots \text { (29) } \\
& \begin{array}{r}
\boldsymbol{S}_{i}=\left[\begin{array}{cccc}
\frac{\varepsilon}{r^{3}} & 0 & 0 & 0 \\
0 & \frac{\varepsilon}{r^{2}} & 0 & 0 \\
0 & \frac{\varepsilon \mu}{2 r^{2}} & \frac{1}{r} & 0 \\
-\frac{\varepsilon \lambda}{6 r^{3}} & 0 & 0 & 1
\end{array}\right]_{i}\left[\begin{array}{cccc}
1 & 1 & 1 & 1 \\
0 & 1 & 2 & 3 \\
0 & 0 & 1 & 3 \\
0 & 0 & 0 & 1
\end{array}\right]= \\
\boldsymbol{S}_{i}^{\prime}=\left[\begin{array}{cccc}
1 & -1 & 1 & -1 \\
0 & 1 & -2 & 3 \\
0 & 0 & 1 & -3 \\
0 & 0 & 0 & 1
\end{array}\right]\left[\begin{array}{cccc}
\frac{\gamma^{3}}{\varepsilon} & 0 & 0 & 0 \\
0 & \frac{r^{2}}{\varepsilon} & 0 & 0 \\
0 & -\frac{1}{2} r \mu & \gamma & 0 \\
\frac{\lambda}{6} & 0 & 0 & 1
\end{array}\right]_{i}=
\end{array}
\end{aligned}
$$

$$
\boldsymbol{N}_{i-1}=-\boldsymbol{c}^{\prime}{ }_{i-1}^{-1} \boldsymbol{c}_{i} \boldsymbol{N}_{i}-K_{i-1}=\boldsymbol{S}_{i}^{\prime} \boldsymbol{N}_{i}-K_{i-1}
$$

式 (29) によって左径間 $(i-1)$ の固有マトリクス $N_{i-}{ }^{1}$ が右径間 (i) の固有マトリクス $N_{i}$ に移行する。このよ うな意味でマトリクス $\boldsymbol{S}_{\boldsymbol{i}}$ を右移行演算子 (rightward shift operator) と呼ぶ。同様に, 式 (30) の $\boldsymbol{S}^{\prime}{ }_{i}$ を左 移行演算子 (leftward shift operator) ${ }^{6)}$ と呼ぶ。普通の はりの場合のこれらの移行演算子の值を式 (31), (32) に示した。弾性床上のはりや軸圧力を受けるはりについ ては, $\boldsymbol{c}^{\prime}{ }_{i-1}, \boldsymbol{c}_{\boldsymbol{i}}$ の逆マトリクスの姿が複雑になるので, これを数式の形で与えずに数值的に解いていくのが望ま $\frac{\varepsilon}{r^{3}} \quad \frac{\varepsilon}{r^{3}} \quad \frac{\varepsilon}{r^{3}} \quad \frac{\varepsilon}{r^{3}}$

$0 \quad \frac{\varepsilon}{r^{2}} \quad \frac{2 \varepsilon}{r^{2}} \quad \frac{3 \varepsilon}{r^{2}}$

$0 \quad \frac{\varepsilon \mu}{2 \gamma^{2}} \quad \frac{1}{r}\left(1+\frac{\varepsilon \mu}{r}\right) \quad \frac{3}{r}\left(1+\frac{\varepsilon \mu}{2 r}\right)$

$\left.-\frac{\varepsilon \lambda}{6 r^{3}}-\frac{\varepsilon \lambda}{6 \gamma^{3}} \quad-\frac{\varepsilon \lambda}{6 \gamma^{3}} \quad 1-\frac{\varepsilon \lambda}{6 \gamma^{3}}\right]_{i}$ $\left[\begin{array}{cccc}\frac{r^{3}}{\varepsilon}-\frac{\lambda}{6} & r\left(\frac{r}{\varepsilon}-\frac{\mu}{2}\right) & r & -1 \\ \frac{\lambda}{2} & r\left(\frac{r}{\varepsilon}+\mu\right) & -2 r & 3 \\ -\frac{\lambda}{2} & -\frac{1}{2} r \mu & r & -3 \\ \frac{\lambda}{6} & 0 & 0 & 1\end{array}\right]_{i}$ 
しい。

これが剛支承またはピンジョイントのみの組み合わせ によって構成されるような連続ばりの解析では, 式(25) または式 (26) の条件を処理することにより，両径間の 半固有マトリクス $\boldsymbol{A}_{i-1}, \boldsymbol{A}_{i}$ の間の移行演算をつぎの形 で進めることができる ${ }^{5)}$ :

$$
\begin{aligned}
& \boldsymbol{A}_{i}=\boldsymbol{L}_{i} \boldsymbol{A}_{i-1}+Q_{i} \boldsymbol{K}_{i-1}+\boldsymbol{R}_{i} \boldsymbol{K}_{i} \cdots \\
& \boldsymbol{A}_{i-1}=\boldsymbol{L}^{\prime}{ }_{i} \boldsymbol{A}_{i}+\boldsymbol{Q}^{\prime}{ }_{i} \boldsymbol{K}_{i-1}+\boldsymbol{R}^{\prime}{ }_{i} \boldsymbol{K}_{i} \cdot
\end{aligned}
$$

ここに, $L_{i}, L^{\prime}{ }_{i}$ は半固有マトリクスの移行演算子で, その次数は 2 行 2 列である。一方, $\boldsymbol{Q}_{i}, \boldsymbol{Q}^{\prime}{ }_{i} \boldsymbol{R}_{i}, \boldsymbol{R}^{\prime}{ }_{i}$ は それぞれ 2 行 4 列の矩形マトリクスで，関係する径間の 荷重項の影響を導入するための演算子である。これらを 補給演算子 (feed operators) と呼ぶ5, ,6)。式 (29) はた またま，移行演算子と補給演算子とが同一のマトリクス で与えられる場合である。

\section{7. 移行演算}

式 (29)，(30)，(33)，(34) は，連続ばりのたがいに

$$
N_{1}=-\left[\begin{array}{c}
B \\
B^{\prime} S_{n} S_{n-1} \cdots S_{2}
\end{array}\right]^{-1}\left[\begin{array}{c}
0 \\
B^{\prime}\left[S_{n} S_{n-1} \cdots S_{2} K_{1}+\cdots+S_{n} S_{n-1} K_{n-2}+S_{n} K_{n-1}+K_{n}\right]
\end{array}\right]
$$

ここに 4 次の逆マトリクスの計算が介入する。これが， 剛支承とピンジョイントのみの組み合わせで構成される ような系の場合には，式形は多少複雑にはなるが，上記 のような手順を用いたときの最終段階での逆マトリクス の次数は 2 次となる。

与えられた系に対する解析手順の設計は，移行チャ一 卜 (shifting chart $)^{6)}$ を用いて進めると都合がよい。図 -3にその一例を手計算による場合について示した。こ こでは最終条件は右端の境界条件で与えられ, 逆マトリ クスの次数は 2 次となる。図の中で, 径間の固有マトリクスの初期の次数，○は条件式の処理

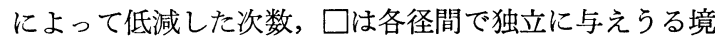
界条件の数， ○は隣り合う径間同士の結合条件の数を示 す。また， $\triangleright は$ 移行の方向である。

\section{8. 図形マトリクス}

流通マトリクスの值が決定すれば，これを移行公式に 代入して系全体の固有マトリクスの值を直ちに求めるこ とができる。この場合の解は，つぎの形で表わされる。 ただし，考えている系を $n$ 径間の連続ばりとした。

$$
\{\boldsymbol{N}\}_{n}=[\boldsymbol{G}]\{\boldsymbol{K}\}_{n}
$$
ここに,

$$
\{\boldsymbol{N}\}_{n}=\left\{\begin{array}{llll}
\boldsymbol{N}_{1} & \boldsymbol{N}_{2} & \boldsymbol{N}_{3} \cdots \boldsymbol{N}_{n}
\end{array}\right\}
$$

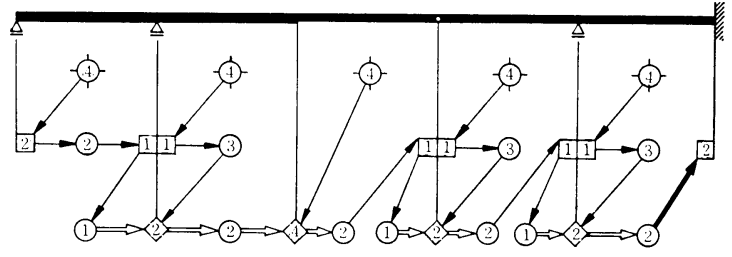

図一了移行 チャ 一

隣り合う径間の固有マトリクスまたは半固有マトリク スの間に導かれた漸化式で，本法ではこれを移行公式

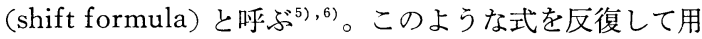
いることにより，基準にえらんだ径間の固有マトリクス を考えている系の径間全体に流通させることができる。 したがって，これを流通マトリクス (current matrix) ${ }^{6)}$ と呼ぶ。このうな移行演算を行なったあとに,両端の境界 条件を式 (20)，(21）の形で処理すると, 流通マトリク スの值が決定される。以上が本法の標準的な手順である。

隣接する固有マトリクスの間の関係が単に, 式 (29) または式（30）で与えられるような系では，左端の第 1 径間の固有マトリクス $N_{1}$ を基準にとって系全体に流通 させたとき，その解はつぎのようになる：

$$
[\boldsymbol{G}]=\left[\begin{array}{ccccc}
\boldsymbol{G}_{11} & \boldsymbol{G}_{12} & \boldsymbol{G}_{13} & \cdots & \boldsymbol{G}_{1 n} \\
\boldsymbol{G}_{21} & \cdots & \cdots & \cdots & \cdots \\
\boldsymbol{G}_{31} & \cdots & \cdots & \cdots & \cdots \\
\cdots & \cdots & \cdots & \cdots & \cdots \\
\boldsymbol{G}_{n 1} & \cdots & \cdots & \cdots & \boldsymbol{G}_{n n}
\end{array}\right]
$$$$
\{\boldsymbol{K}\}_{n}=\left\{\begin{array}{llllll}
\boldsymbol{K}_{1} & \boldsymbol{K}_{2} & \boldsymbol{K}_{3} & \cdots & \boldsymbol{K}_{n}
\end{array}\right\}
$$

マトリクス $[\boldsymbol{G}]$ は $4 n$ 次の正方マトリクスである。こ れは，構成部材の材質 $E$ と図形量 $I, L$ のみによって 決定し得るものであって，荷重条件とは全く無関係であ る。よってこれを図形マトリクス (geometry matrix) ${ }^{6)}$ と名づける。この值を求めておけば，どのような荷重条 件についてでも，それに対応する固有マトリクスの值が ただちに計算され，すべての物理量の值が式 (2) によ って与えられることになる。また，図形マトリクスを用 いて, 各種の影響線も数式の形で得ることができる。具 体例については以下の例題に示す。

\section{9. 計 算 例}

\section{例 題 1 .}

図一4 に示した 2 径間の連続ばりについて， $E, I, L$ が両径間ともに等しいものとして計算すれば，図形マト リクスはつぎのように得られる： 


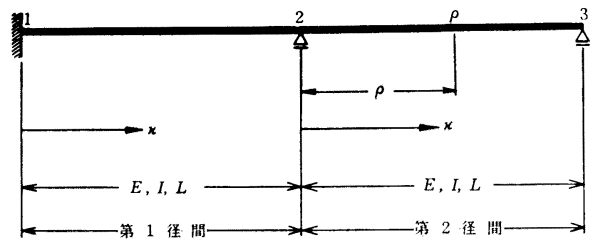

図-4 2 径間の連続ばり

$$
[\boldsymbol{G}]=\frac{1}{7}\left[\begin{array}{rrrrrrrr}
0 & 0 & 0 & 0 & 0 & 0 & 0 & 0 \\
0 & 0 & 0 & 0 & 0 & 0 & 0 & 0 \\
-15 & -12 & -7 & 0 & 3 & 3 & 2 & 0 \\
8 & 5 & 0 & -7 & -3 & -3 & -2 & 0 \\
0 & 0 & 0 & 0 & 0 & 0 & 0 & 0 \\
-6 & -2 & 0 & 0 & -3 & -3 & -2 & 0 \\
9 & 3 & 0 & 0 & -6 & -6 & -4 & 0 \\
-3 & -1 & 0 & 0 & 2 & 2 & -1 & -7
\end{array}\right]
$$

この值を用いて各種物理量の影響線を求めた結果をつぎ に示した。ただし， $\kappa$ は単位荷重 $P=1$ の無次元座標 で, 図のように各径間の左端からとるものとする。

(a) 埋込端 1 の曲げモーメントの影響線の式

第 1 径間 :

$$
\begin{aligned}
& M_{1}=L\left(-0.714 \kappa^{3}+1.714 \kappa^{2}-\kappa\right) \\
& \text { 第 } 2 \text { 径間 : } \\
& M_{1}=L\left(0.143 \kappa^{3}-0.429 \kappa^{2}+0.286 \kappa\right)
\end{aligned}
$$

（b）中間支点 2 のたわみ角の影響線の式

第 1 径間 :

$$
\theta_{2}=\frac{L^{2}}{E I}\left(0.143 \kappa^{3}-0.143 \kappa^{2}\right)
$$

第 2 径間 :

$$
\theta_{2}=\frac{L^{2}}{E I}\left(0.071 \kappa^{3}-0.214 \kappa^{2}+0.143 \kappa\right)
$$

（c）左支点 3 の反力の影響線の式

第 1 径間 :

$$
V_{3}=0.429\left(-\kappa^{3}+\kappa^{2}\right)
$$

第 2 径間 :

$$
V_{3}=0.286 \kappa^{3}-0.857 \kappa^{2}-0.429 \kappa
$$

(d) 第 2 径間の任意点 $\rho$ におけるたわみの影響線 の式

第 1 径間 :

$$
w_{\rho}=\frac{L^{3}}{2 E I}\left(\rho^{3}-3 \rho^{2}+2 \rho\right)\left(\kappa^{3}-\kappa^{2}\right)
$$

第 2 径間 $\rho$ 点より左側 :

$$
\begin{aligned}
w_{\rho}= & \frac{L^{3}}{6 E I}\left[\left(-2 \rho^{3}+6 \rho^{2}+3 \rho-7\right) \kappa^{3}\right. \\
& +\left(6 \rho^{3}-18 \rho^{2}+12 \rho\right) \kappa^{2} \\
& \left.+\left(3 \rho^{3}-12 \rho^{2}+6 \rho\right) \kappa\right]
\end{aligned}
$$

第 2 径間 $\rho$ 点より右側 :

$$
\begin{aligned}
w_{\rho}= & \frac{L^{3}}{6 E I}\left[\left(-2 \rho^{3}+6 \rho^{2}+3 \rho\right)\left(\kappa^{3}-3 \kappa^{2}\right)\right. \\
& \left.+3\left(\rho^{3}+4 \rho^{2}+2 \rho\right) \kappa-7 \rho^{3}\right]
\end{aligned}
$$

\section{例 題 $2^{8)}$}

図一5 は簡単なドルフィンを示す。(1)の部分は普通の

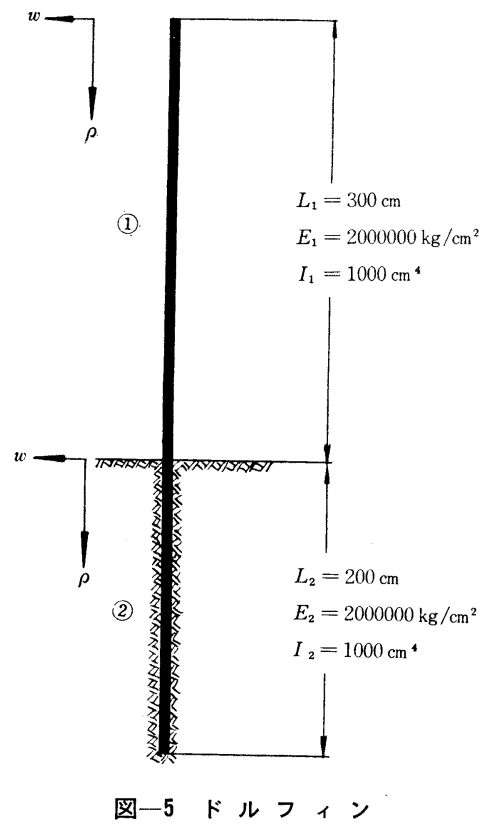

はりとしての力学挙動を示し, (2)の地盤内に埋めこまれ た部分は，そこに生ずるたわみと地盤反力とが比例する ものと仮定すれば，これを弾性床上のはりとして取り扱 うことができる。よってこのような系を解くことは，普 通のはりと弾性床上のはりとを結合する問題に帰着す る。まず，(1)および(2)のはりについて，端部の境界条件 を個別に処理して, それぞれの固有マトリクスの次数を 2 次に低減させる。このようにしたのちに，おのおのの はりの基本式に注目しながら結合点における状態べクト ルの結合条件を処理すればよい。この場合の解はつぎの 形で与えられる：

$$
\left\{\begin{array}{ll}
\boldsymbol{N}_{0} & \boldsymbol{N}_{e}
\end{array}\right\}=[\boldsymbol{G}] \begin{cases}\boldsymbol{K}_{0} & \left.\boldsymbol{K}_{\boldsymbol{e}}\right\}\end{cases}
$$

ここに， $\boldsymbol{N}_{0}, \boldsymbol{N}_{e}$ はそれぞれ，はり(1)，(2)の固有マトリ クスである。また， $\boldsymbol{K}_{0}$ には式 (15) で与えられるよう な普通のはりの荷重マトリクスを用い， $\boldsymbol{K}_{e}$ には式 (16) で与えられるような弾性床上のはりの荷重マトリクスを 用いることになる。

図一5 に示したような值について電算を用いて計算し た結果, 図形マトリクスはつぎのように得られた。ただ し，地盤係数 $K=10 \mathrm{~kg} / \mathrm{cm}^{2}$ とした。 


$$
[\boldsymbol{G}]=\left[\begin{array}{rrrccccc}
-1 & 0 & 4.204 & 14.655 & -2.629 & 9.375 & 1.572 & -1.402 \\
0 & -1 & -4.491 & -12.612 & 1.195 & -7.270 & -1.195 & 1.109 \\
0 & 0 & 0 & 0 & 0 & 0 & 0 & 0 \\
0 & 0 & 0 & 0 & 0 & 0 & 0 & 0 \\
0 & 0 & 0.014 & 0.080 & -1.040 & 0.063 & 0.040 & 0.017 \\
0 & 0 & -0.363 & -1.407 & 0.317 & -1.928 & -0.317 & 0.294 \\
0 & 0 & 1.335 & 5.678 & -1.674 & 3.919 & 0.674 & -0.571 \\
0 & 0 & -0.958 & -3.191 & 0.317 & -1.928 & -0.317 & 0.294
\end{array}\right]
$$

\section{例 題 $3^{7)}$}

軸圧力を受けるはりの基本式は, 連続長柱の固有值問 題に応用することができる。危険荷重は, 芒 (35) の姿 を参照すれば結局, 条件式

$$
\left|\begin{array}{c}
B \\
B^{\prime} \boldsymbol{S}_{n} \boldsymbol{S}_{n-1} \cdots \boldsymbol{S}_{2}
\end{array}\right|=0
$$

を満足させるような軸力值 $Q$ を見出す問題となること がわかる。図一6 に示すような 4 種類の系について危険 荷重の值を求めたところ, 表一4 のような結果を得た。 2 次, 3 次の固有値も一応, 参考までに記載した。

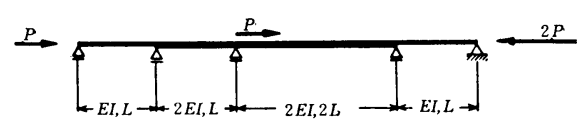

(a)

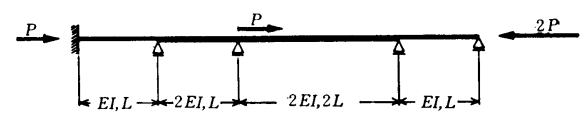

(b)

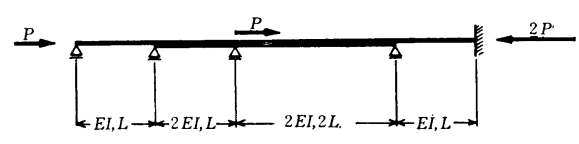

(c)

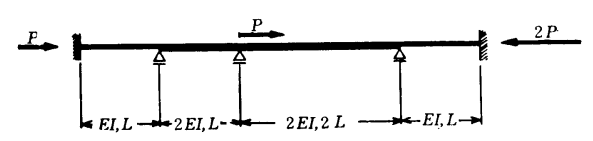

(d)

図一6軸圧力を受ける連続ばり

表-4 危 険 荷 重 $\left(\times \frac{E I}{L^{2}}\right)$

\begin{tabular}{rr|r|r|r|r}
\hline & & 系 (a) & 系 (b) & 系 (c) & 系 (d) \\
\hline 1 & 次 & 4.266 & 4.286 & 5.052 & 5.087 \\
2 & 次 & 8.556 & 8.461 & 10.933 & 11.197 \\
3 & 次 & 12.943 & 13.471 & 15.364 & 17.563 \\
\hline
\end{tabular}

\section{例 題 $4^{7 \text { ) }}$}

図一7 のようなラーメンは, 各部材の伸縮を無視すれ ば，連続ばりの場合と同じ手順で解くことができる。こ の系の図形マトリクスを求め, それより第 1 径間の任意

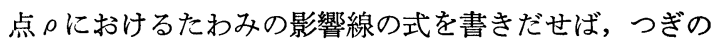
ようである :

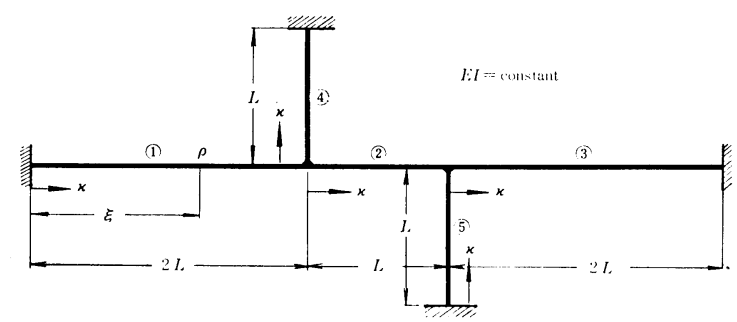

図一7 節点移動の生じない゙ラーメン

第 1 径間 $\rho$ 点より左側 :

$$
\begin{aligned}
w= & \frac{4 L^{3}}{3 E I}\left[-\kappa^{3}+3 \kappa^{2} \rho+\left(2.688 \kappa^{3}-5.688 \kappa^{2}\right) \rho^{2}\right. \\
& \left.+\left(1.688 \kappa^{3}+2.688 \kappa^{2}\right) \rho^{3}\right]
\end{aligned}
$$

第 1 径間 $\rho$ 点より右側 :

$$
\begin{aligned}
w= & \frac{4 L^{3}}{3 E I}\left[\left(2.688 \kappa^{3}-5.688 \kappa^{2}+3 \kappa\right) \rho^{2}\right. \\
& \left.+\left(1.688 \kappa^{3}+2.688 \kappa^{2}-1\right) \rho^{3}\right]
\end{aligned}
$$

第 2 径間 :

$$
w=\frac{4 L^{3}}{3 E I}\left(0.125 \kappa^{2}-0.281 \kappa+0.156\right)(\rho-1) \kappa \rho^{2}
$$

第 3 径間 :

$$
\begin{aligned}
w= & \frac{4 L^{3}}{3 E I}\left(-0.062 \kappa^{2}+0.125 \kappa-0.063\right) \cdot \\
& \cdot(\rho-1) \kappa \rho^{2}
\end{aligned}
$$

第 4 径間 :

$$
w=\frac{4 L^{3}}{E I}\left(0.052 \kappa^{2}-0.104 \kappa+0.052\right)(\rho-1) \kappa \rho^{2}
$$

第 5 径間 :

$$
w=\frac{0.04 L^{3}}{E I}(-\kappa+1)(\rho-1) \kappa^{2} \rho^{2}
$$

\section{0. あとがき}

本法は，ネットワーク系構造物のトポロジカルな性質 に注目した解析法である。ここでは, 連続ばりの解法を 普通のはり, 弾性床上のはりおよび軸圧力を受けるはり の 3 種類の系について総括的に述べた。これと全く同じ 手順で, 軸圧力を受ける弾性床上の連続ばり, 連続ばり の自由振動等の解析もできる。

演算子法では, はりの未知量をその微分方程式の一般 解の積分定数群に選んでおり, 状態ベクトル ${ }^{16), 17) ~}$ は式 (2) の形で与え，これを移行の対象としていない。ま 
た本法は性質の異なるデータをそれぞれのマトリクスに よって完全に分類した形から解析が出発しているため, 構成径間の両端の状態ベクトルの関係は, 単に座標マト リクス $\boldsymbol{P}$ と荷重項 $\boldsymbol{K}$ の值をかえるだけのことになる。 移行演算は常に, 未知量たる固有マトリクス $\boldsymbol{N}$ と, 既 知量たる荷重項 $\boldsymbol{K}$ とが完全に分離された姿で進められ る。そして結果として図形マトリクスが得られる。図形 マトリクスは，例題 1 にも示したように，実用上，設計 問題に応用すると有効である。

本研究にあたって筆者らは，信州大学助教授 夏目正 太郎先生からは, 電算のプログラミングに関して, 数多 くのご指導をいただいた。本文の例題 2 , 例題 3 は, 当 学の FACOM 231 によるものである。また, 信州大学 工学部 浜野浩幹教官, 石川清志技官からは, 数式の検 算について多大のご協力を得た。終りにあたって, 上記 の諸氏に対して深く感謝の意を表します。

\section{記 号}

本文で用いた記号をつぎに示す。各種のマトリクスに ついては, [ ] の中にその次数を示した。 $[m \times n]$ は $m$ 行 $n$ 列のアトリクスを表わす。

$$
\boldsymbol{A}=\text { 半固有マトリクス }[2 \times 1] \text { (式 } 24)
$$

$A, B, C, D=$ 固有マトリクスの要素（式 13）

$\boldsymbol{B}, \boldsymbol{B}^{\prime}=$ 境界マトリクス $[2 \times 4] （$ 式 20,21 ）（表一 1)

$\boldsymbol{C}=$ 結合マトリクス $[4 \times 8] （$ 式 27）（表一2）

$D=$ 倸数マトリクス $[4 \times 4]($ 式 $4,5,6)$

$E=$ 弹性係数

$\boldsymbol{F}=$ 補給演算子 $[4 \times 4]$

$\boldsymbol{G}=$ 図形マトリクス（式 38）

$I=$ 断面二次モーメント

$\boldsymbol{K}=$ 荷重項 $[4 \times 1]$ (式 21)

$\boldsymbol{K}(\rho)=\rho$ 点の荷重マトリクス $[4 \times 1]($ 式 15,16 , 17)

$K=$ 地盤保数

$k=w / V=$ ね权定数（図一2）

$\boldsymbol{L}, \boldsymbol{L}^{\prime}=$ 半固有マトリクスの移行演算子 $[2 \times 2]$ (式 $33,34)$

$L=$ はりの長さ

$M=$ 曲げモーメント

$m=\theta / R=$ ばね定数（図一2）

$\mathfrak{M}=$ 外力モーメント

$N=$ 固有マトリクス $[4 \times 1] （$ 式 13）

$\boldsymbol{P}(\rho)=\rho$ 点の座標マトリクス $[4 \times 4]$ (式 9,10 ,

12)

\section{$P=$ 集中荷重}

$\boldsymbol{Q}, \boldsymbol{Q}^{\prime}=$ 半固有マトリクスの補給演算子 $[2 \times 4]$ (式
$33,34)$

$$
Q=\text { 軸力 }
$$

$q(x)=$ 分布荷重の強度

$\boldsymbol{R}, \boldsymbol{R}^{\prime}=$ 半固有マトリクスの補給演算子 $[2 \times 4]$ (式 $33,34)$

$\boldsymbol{S}, \boldsymbol{S}^{\prime}=$ 移行演算子 $[4 \times 4]$ （式 31,32 )

$S=$ せん断力

$\boldsymbol{W}(\rho)=\rho$ 点における状態ベクトル $[4 \times 1] （$ 式 2 ， 3)

$$
\begin{aligned}
w & =\text { たわみ } \\
x & =\text { はりの流通座標 } \\
\alpha & \left.=\sqrt{Q L^{2} / E I} \text { (式 } 8\right) \\
\beta & \left.=\sqrt[4]{K L^{4} / 4 E I} \text { (式 } 6\right) \\
\theta & =\text { たわみ角 } \\
\kappa & =\xi / L=\text { 無次元荷重座標 } \\
\xi & =\text { 荷重座標 }(\text { 図一1) } \\
\rho & =x / L=\text { 無次元流通座標 } \\
& \text { 参 考 文 献 }
\end{aligned}
$$

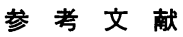

1) S.U. Benscoter : "Matrix Analysis of Continuous Beams", Transactions of the ASCE, Vol. 112, 1947, pp. 1109-1140.

2) B.E. Gatewood and N. Ohanian: "Tri-Diagonal Matrix Method for Complex Structures", Proceedings of the ASCE, Structural Division, April, 1965, pp. 2741.

3) B. Tanimoto: "Operational Method for Continuous Beams", Proceedings of the ASCE, Structural Division, Dec., 1964, pp. 213-242.

4) B. Tanimoto: "Operational Method for Pin-Jointed Trusses", Proceedings of the ASCE, Structural Division, June, 1966, pp. 179-198.

5) N. Yoshizawa and B. Tanimoto: "Operational Method for Continuous Beams, First Report, Rigid Support and Pin Joint", Journal of the Faculty of Engineering, Shinshu University, Vol. 20, June, 1966, pp. 1-29.

6) N. Yoshizawa and B. Tanimoto: “Operational Method for Continuous Beams, Second Report, Generalized Continous Beams", Journal of the Faculty of Engineering, Shinshu University, Vol. 20 June, 1966, pp. 31-60.

7) N. Yoshizawa and B. Tanimoto: "Subsidiary Operational Method for Continuous Beam-Columns", Journal of the Faculty of Engineering, Shinshu University, Vol. 23, Dec., 1967, pp. 15-34.

8) S. Natsume, N. Yoshizawa, H. Hamano, K. Ishikawa and B. Tanimoto: "Operational Method for Various Continuous Beams", Journal of the Faculty of Engineering, Shinshu University, Vol. 24, July, 1968, pp. 1-21.

9) B. Tanimoto: "Eigen-Matrix Method for Beams and Plates", Proceedings of the ASCE, Structural Division, Oct., 1963, pp. 173-215.

10）谷本勉之助・吉沢孝和：“詳説マトリクス応用力学”, オ 一公社, 1966, pp. 23-266.

11）小西一郎・横尾 義貫・成岡昌夫 : “構造力学”, 丸 善, pp. $95-215$. 
12) N. Yoshizawa and B. Tanimoto, "Comments on Prevailing Methods of Structural Analysis", Journal of the Faculy of Engineering, Shinshu University, Vol . 22, July, 1967, pp. 49-64.

13）中川健治・成岡昌夫：“変形法と Reduction 法との相互 関係について”, 土木学会論文集, 141号, 1967, pp. 2330.

14) N. Yoshizawa and B. Tanimoto : "Operational Method for Clapeyron's Theorem", Journal of the Faculty of Engineering, Shinshu University, Vol. 18, Dec., 1964, pp. 1-39.

15) N. Yoshizawa and B. Tanimoto : "Oprational Method for Displacement Analysis, First Report, Slope-Deflection Method for Rigid Frames", Journal of the Faculty of Engineering, Shinshu University, Vol. 22, July, 1967, pp. 13-25.

16) E.C. Pestel and F.A. Leckie, "Matrix Methods in Elastomechanics", Mc-GRAW Hill Book Co. Inc., 1963, pp. 51-60.

17）伊藤 学訳：R. ケルステン, “㥍造力学における嗃元 法”, 技報堂, 1968, p. 17 .

18) S. Timoshenko: "Strength of Materials, Part II", D. Van Nostrand Co. Inc., 1956, pp. 1-56.

(1968.8.12 - 受付) 